\title{
Mapping the Logic of Value in Higher Education - A Theoretical Adaption of Service-Dominant Logic and Empirical Case Study in the Context of Executive Education
}

\author{
David Wawrzinek, M.A. \\ University of Bayreuth, Germany, Chair in Marketing and Service Management
}

\begin{abstract}
Strategic management tools for controlling processes, decision-making, goal achievement and -measurement are useful when it comes to governing complexity and resulting uncertainties in higher education institutions (HEI). A strategy map is such a useful tool with many advantages. This article specifically develops and describes a modified strategy map for the field of executive education. This small-scale qualitative study uses a sample of MBA students at a German university in focus groups and additionally a number of German university presidents in expert interviews. As a strategic management and navigation tool for deciders a thematic analysis was implemented into an executive education strategy map (EESM). The key themes (goals) represent the different value drivers and value added perspectives of the actors society, university presidents and MBA students. The EESM integrates theoretical findings of the service-dominant logic and provides a suitable basis for a high-quality performance indicator system, for example in the form of a modified balanced scorecard to manage and control executive education offerings.
\end{abstract}

Keywords: higher education management; strategy map; executive education; servicedominant logic; decision-making 